\title{
RESEARCH
}

\section{Characterization of the 55-kb Mouse Histone Gene Cluster on Chromosome 3}

\author{
Zeng-Feng Wang, ${ }^{1}$ Rich Tisovec, ${ }^{1}$ Ron W. Debry, ${ }^{6}$ Mark R. Frey, ${ }^{4}$ \\ A. Gregory Matera, ${ }^{4,5}$ and William F. Marzluff ${ }^{1-3,7}$
}

${ }^{1}$ Department of Biology, ${ }^{2}$ Department of Biochemistry and Biophysics, ${ }^{3}$ Program in Molecular Biology and Biotechnology, University of North Carolina (UNC) at Chapel Hill, Chapel Hill, North Carolina 27599-7100; ${ }^{4}$ Department of Genetics, ${ }^{5}$ Center for Human Genetics, Case Western Reserve University School of Medicine, and University Hospitals of Cleveland, Cleveland, Ohio 44106-4955; ${ }^{6}$ Department of Biological Sciences, University of Cincinnati, Cinncinati, Ohio 45221-0006

The histone gene cluster on mouse chromosome 3 has been isolated as a series of overlapping PI clones, covering $110-120 \mathrm{~kb}$, by probing with the histone $\mathrm{H} 3-614$ gene that had been mapped previously to mouse chromosome 3 . There are genes for 10 core histone proteins present in a 55-kb cluster within this contig. There are three histone $\mathrm{H} 3$ genes, two of which are identical; four histone $\mathrm{H} 2 \mathrm{a}$ genes, two of which are identical, one histone $\mathrm{H} 4$ gene; and two histone $\mathrm{H} 2 \mathrm{~b}$ genes. These histone $\mathrm{H} 3$ and $\mathrm{H} 2 \mathrm{a}$ genes encode $\sim 40 \%$ of the total $\mathrm{H} 3$ and $\mathrm{H} 2 \mathrm{a}$ mRNA, whereas the histone $\mathrm{H} 4$ and histone $\mathrm{H} 2 \mathrm{~b}$ genes encode $<10 \%$ of the total $\mathrm{H} 4$ and $\mathrm{H} 2 \mathrm{~b}$ mRNA. There are no histone $\mathrm{Hl}$ genes present in this cluster. All of the histone $\mathrm{H} 2 \mathrm{a}$ genes encode histone $\mathrm{H} 2 \mathrm{a} .2$ proteins (or variants of H2a.2), and account for all the H2a.2 genes in the mouse genome. All three histone $\mathrm{H} 3$ genes encode the histone $\mathrm{H} 3.2$ protein. A 2.l-kb region containing the adjacent $\mathrm{H} 3-614$ and $\mathrm{H} 2 \mathrm{a}-614$ genes has been duplicated and is present in an inverted repeat separated by $4.5 \mathrm{~kb}$. The other two H2a genes are adjacent, with the $3^{\prime}$ ends of their mRNAs separated by only 49 nucleotides in the DNA and the U7 snRNP binding sites separated by only 20 nucleotides. One of the histone $\mathrm{H} 2 \mathrm{~b}$ genes has lost the stem-loop sequence characteristic of the replication-dependent histone mRNAs and encodes only polyadenylated mRNAs.

The histone proteins are encoded by a multigene family, consisting of 10-20 genes for each of the core histone proteins in mammals (Jacob 1976). Most of the histone genes are replication dependent, and their mRNAs are expressed coordinately with DNA replication. The replicationdependent histone mRNAs are the only metazoan mRNAs that lack a poly(A) tail, ending instead in a highly conserved 26 nucleotide sequence that can form a stem-loop (Birnstiel et al. 1985; Marzluff 1992). The histone genes in mammals are present in two clusters on separate chromosomes; chromosomes 1 and 6 in humans (Triputti et al. 1986) and chromosomes 3 and 13 in mouse (Graves et al. 1985b). The majority of the replication-dependent histone genes (Graves et al. 1985b), including all the histone $\mathrm{H} 1$ genes (Wang et al. 1996), are on mouse chromosome 13, and human chromosome 6 (Doenecke et al.
1994), whereas a smaller number of genes are present on mouse chromosome 3 and human chromosome 1 . Two of the genes on mouse chromosome 3, H3-614 and H2a-614, encode a significant fraction of the histone $\mathrm{H} 3$ and H2a mRNA (Graves et al. 1985b), suggesting that the minor histone gene cluster makes an important contribution to the total histone mRNA population.

We have described a $2-\mathrm{Mb}$ region from mouse chromosome 13 containing 45 histone genes (Wang et al. 1996). Here we describe a 120$\mathrm{kb}$ region containing 10 histone genes clustered in $55 \mathrm{~kb}$ on mouse chromosome 3 . There are genes for all four core histones present in this cluster. There are four $\mathrm{H} 2 \mathrm{a}$ genes and three $\mathrm{H} 3$ genes, which produce a significant fraction of the total histone $\mathrm{H} 3$ and $\mathrm{H} 2 \mathrm{a}$ RNA. The two H2b genes and single $\mathrm{H} 4$ gene, in contrast, are expressed at a low level.

\section{RESULTS}

We previously identified two histone genes, H2a- 


\section{MOUSE HISIONE GENE CLUSTER ON CHROMOSOME 3}

614 and H3-614, which mapped to mouse chromosome 3 (Graves et al. 1985b). To see whether there were other histone genes linked to these genes, we screened a P1 library by PCR with specific primers flanking the histone H3-614 gene. Four overlapping P1 clones (P0, P1, P2, and P3), which formed a single contig, were obtained. Each of these P1 clones contained multiple histone genes. Because some of these genes were close to the end of this contig, the P1 library was rescreened with primers specific for the end of the P0 clone. Two additional P1 clones (P91 and P92) were obtained, but these extended the contig only an additional $9 \mathrm{~kb}$. By use of a probe from the end of the P92 clone, we screened a genomic library and isolated a $\lambda$ phage, $\lambda 111$, which extended the contig an additional $12 \mathrm{~kb}$. By use of gene specific probes we identified genes for all of the core histones in this contig by Southern blotting.

There were 10 histone genes identified in a 55-kb region, which was completely included in clone P0 (Fig. 1). Flanking these genes was at least $40 \mathrm{~kb}$ on one end and $22 \mathrm{~kb}$ on the other end with no additional histone genes. Southern blots identified three histone $\mathrm{H} 3$ genes (Fig. 2A), three fragments containing histone $\mathrm{H} 2 \mathrm{a}$ genes (one of which contained two H2a genes; Fig. 2B), a single histone $\mathrm{H} 4$ gene, and two histone $\mathrm{H} 2 \mathrm{~b}$ genes (Fig. 2C). By use of specific probes for the H2a-614 and H2a-615 5' flanking regions and the H3-614 and H3-615 3' flanking regions, we determined that the $5^{\prime}$ ends of the H2a-614 and H2a-615 genes were on the same Sall fragment, whereas the $3^{\prime}$ ends of the H3-614 and H3-615 genes were on different SalI fragments (Fig. 2D). Thus, this cluster is oriented with the $5^{\prime}$ ends of the $\mathrm{H} 2$ a genes juxtaposed. Figure 1 shows a map of this region, with the location and orientation of the histone genes indicated.

\section{The Hist2 Gene Cluster Maps to Mouse Chromosome 3FI-2}

By use of fluorescence in situ hybridization (FISH), we hybridized one $\lambda$ clone and four phage P1 clones to mouse metaphase chromosomes. The signals from each probe showed exclusive hybridization to chromosome 3F1-2. No crosshybridization to the Hist 1 locus on chromosome 13 was detected. Examples of these images are shown in Figure 3, A and B. DAPI $(\mathrm{G} / \mathrm{Q})$ banding patterns place the Hist2 cluster within the proximal half of band 3F; fractional length measure-

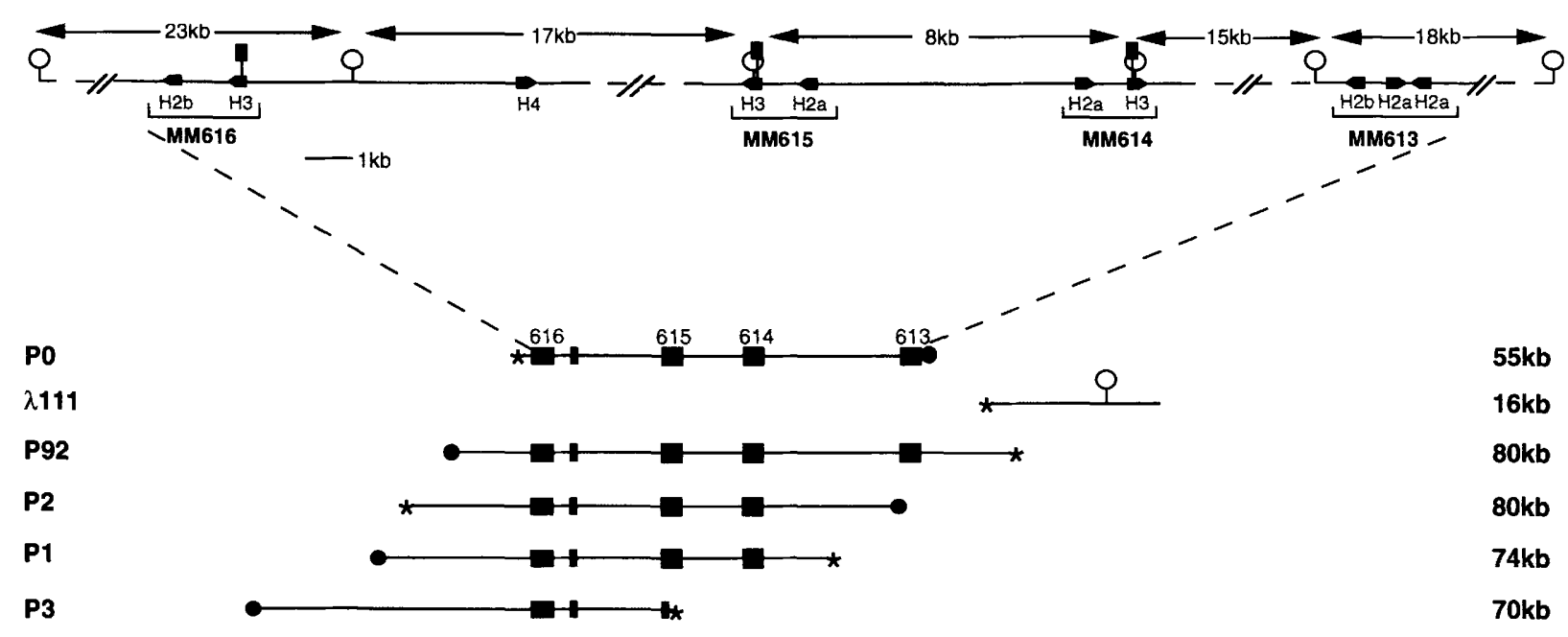

Figure 1 Structure of the histone gene cluster on chromosome 3. A schematic of the histone gene cluster on chromosome 3, with the orientation of each gene, is shown. The structure of the P1 clones used to deduce the organization of the cluster is included and the position of the Sall sites $(O)$ and Sfil sites ( $\square$ ) on the clones are indicated. $\lambda 111$ is the $\lambda$ phage that overlaps the end of the P92 clone. (*) T7 promoter; (0) SP6 promoter. The position of the genes was determined by use of Southern blotting (Fig. 2). The orientation of the H2a-613 and $\mathrm{H} 2 \mathrm{~b}-613$ genes was determined by cloning the end of the $\mathrm{PO}$ clone and sequencing. The orientation of the $\mathrm{H} 2 \mathrm{~b}-616$ and $\mathrm{H} 3-616$ genes was determined by analysis of Sfil digests of the P0 and P3 clone DNA with probes specific to the $5^{\prime}$ - and $3^{\prime}$-flanking regions of the $\mathrm{H} 3-615$ and $\mathrm{H} 3-616$ genes. The orientation of the $\mathrm{H} 4$ gene was determined by PCR amplification of a fragment from the 3' end of the H3-616 gene to the $\mathrm{H} 4$ gene and was confirmed by sequencing of this fragment. 
ments were in good agreement with these results and allowed us to refine the locus to the F1F2 subregion (see Fig. 3C; FLpter $=58-66 \%)$.

The Histone $\mathrm{H} 2 \mathrm{a}-614$ and H3-614 Genes Are Duplicated

The regions containing the histone genes were cloned and sequenced. Surprisingly, two of the linked histone $\mathrm{H} 3$ genes and histone $\mathrm{H} 2 \mathrm{a}$ genes were nearly identical (24 changes out of 1720 nucleotides) in the coding and intragenic regions. The region of near identity extended for 2122 nucleotides, from 323 nucleotides $5^{\prime}$ of the start of the $\mathrm{H} 2 \mathrm{a}$ protein to just past the U7 snRNP-binding site in the $\mathrm{H} 3$ gene (Fig. 4B). One of these pairs was the previously cloned H2a-614 and H3614 genes, and the other pair was named H2a-615 and H3615 . The position and orientation of these two sets of genes was unambiguously established by use of probes 3 ' of the $\mathrm{H} 3$ genes and $5^{\prime}$ of the $\mathrm{H} 2 \mathrm{a}$ genes in Southern blots (Fig. 2D). The H2a-614 and H2a-615 5 ' flanking probes hybridized to the same 8-kb Sall fragment, present on clones $\mathrm{P} 0, \mathrm{P} 1$, and P2 but not on P3, demonstrating that these genes were located next to each other (Fig. 2D, lanes 1-6). The H3-614 3'flanking probe hybridized to a $15-\mathrm{kb}$ SalI fragment that was present only on clones P0, P1, and P2 but not on P3 (Fig. 2D, lanes 7-9). The H3-615 3'flanking region probe hybridized with a 17-kb SalI fragment present on all the P1 clones (Fig. 2D, lanes 10-12). The 3' end of the H3-615 gene was the probe that hybridized with clone $\mathrm{P} 3$, indicating that this clone ended between the H2a-615 and H3-615 genes.
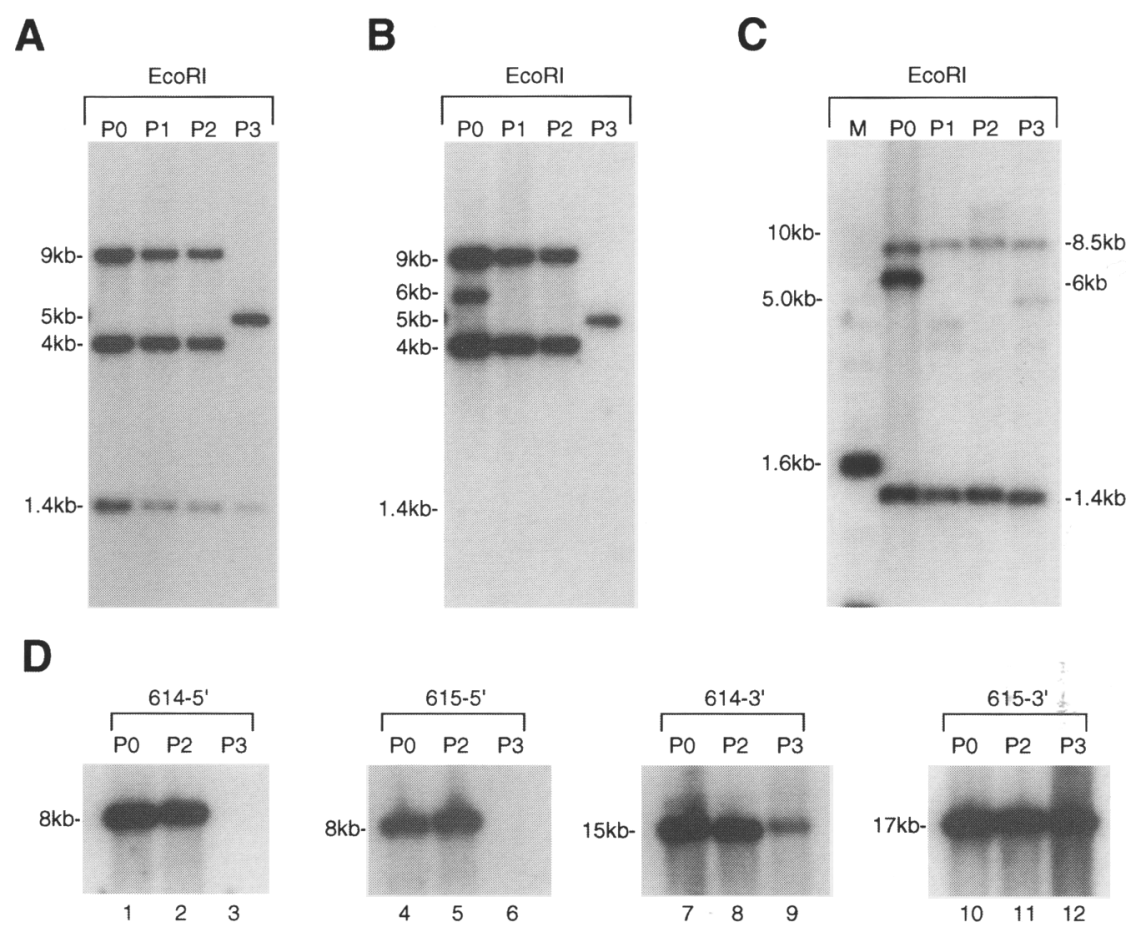

Figure 2 Localization of the genes by Southern analysis. (A) DNA from the P0-P3 clones were digested with EcoRI and hybridized with a probe containing the coding region and part of the 5'-flanking region of the $\mathrm{H3}-614$ gene. The size of the hybridizing fragments is indicated. The 9-kb fragment is the $\mathrm{H} 3-614$ gene, the 4-kb fragment is the H3-615 gene, and the 1.4-kb fragment is the H3-616 gene. The 5-kb fragment on the P3 clone is from the $5^{\prime}$ end of the $\mathrm{H} 3-615$ gene, a result of the P3 clone ending in the fragment containing the $\mathrm{H} 2 \mathrm{a}-615$ and $\mathrm{H} 3-615$ genes. $(B)$ The $\mathrm{P} 0-\mathrm{P} 3$ clones were digested with EcoRI and hybridized with the $\mathrm{H} 2 \mathrm{a}-614$ gene (coding region plus 500 nucleotides of $5^{\prime}$ - and 300 nucleotides of $3^{\prime}$-flanking region). The $9-\mathrm{kb}$ fragment is the $\mathrm{H} 2 \mathrm{a}-615$ gene, the 4-kb fragment is the $\mathrm{H} 2 \mathrm{a}-614$ gene, and the 6-kb fragment is the $\mathrm{H} 2 \mathrm{a}(\mathrm{A})-613$ and $\mathrm{H} 2 \mathrm{a}(\mathrm{B})-613$ genes. The $5-\mathrm{kb}$ fragment in the $\mathrm{P} 3$ clone is the $\mathrm{H} 2 \mathrm{a}-615$ gene, a result of the clone ending in the fragment containing the $\mathrm{H} 2 \mathrm{a}$ and $\mathrm{H} 3-615$ genes. $(C)$ The P0-P3 clones were digested with EcoRI and hybridized with the $\mathrm{H} 2 \mathrm{~b}-143$ gene (Brown et al. 1996). The 1.4-kb fragment is the $5^{\prime}$ portion of the H2b-616 gene. The 8.5-kb fragment is from the $3^{\prime}$ portion of the $\mathrm{H} 2 \mathrm{~b}-616$ gene, which contains an EcoRI site. The 6-kb fragment from the $\mathrm{PO}$ clone is the $\mathrm{H} 2 \mathrm{~b}-613$ gene. $(D)$ The orientation of the 614 and 615 gene cluster. The P0, P2, and P3 clones were digested with Sall, resolved by electrophoresis on a $0.8 \%$ agarose gel, transferred to Nytran, and hybridized with specific probes for the $\mathrm{H} 2 \mathrm{a}-614$ $5^{\prime}$-flanking region (614-5', lanes $1-3$ ), the $\mathrm{H} 2 \mathrm{a}-615$ 5'-flanking region (615$5^{\prime}$, lanes 4-6), the H3-614 3'-flanking region (614-3', lanes 7-9), and the H3-615 3'-flanking region (615-3', lanes 10-12). The size of the hybridizing fragments is indicated. The weak $17-\mathrm{kb}$ band detected by the $614-3^{\prime}$ probe in the P3 DNA is from contamination of the probe with a small amount of vector DNA, which hybridizes with the 17-kb P1 vector.

This result unambiguously places the $3^{\prime}$ end of the H3-615 gene near one end of the cluster defined by clone P3. These results also demonstrate 

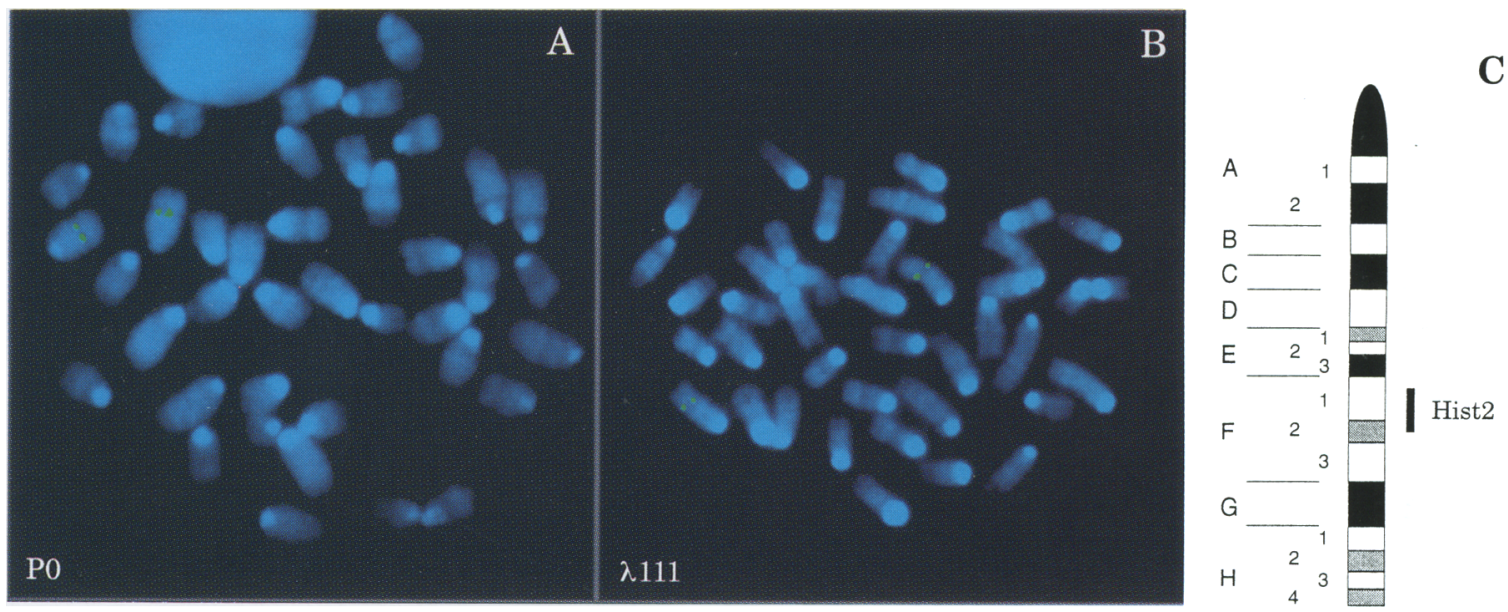

Figure 3 Chromosomal location of the mouse Hist2 gene cluster. Biotin-labeled mouse histone clones P0 $(A)$ and $\lambda 111$ (B) map to chromosome 3 (green). DAPI staining generated the G/Q banding pattern in both panels (blue). (C) An ideogram of mouse chromosome 3. The bar (at right) indicates that the range of signals for these probes localizes to $3 \mathrm{~F} 1-2$.

that the $5^{\prime}$ ends of the $\mathrm{H} 2 \mathrm{a}$ genes are juxtaposed and that these gene pairs are oriented as shown in Figure 1.

\section{The Histone H3-614, H3-615, and H3-616 Genes}

In addition to the H3-615 gene, there was an additional histone $\mathrm{H} 3$ gene, H3-616, located $\sim 20 \mathrm{~kb}$ from the H3-615 gene. This gene also encodes a H3.2 protein. The coding region of the gene contains only 4-nucleotide changes from the H3-614 and H3-615 genes (Fig. 4A). The 5'-untranslated and flanking region is completely different from the H3-614 and H3-615 genes, but the 3'untranslated region is nearly identical to the H3614 and H3-615 sequence to the end of the mRNA (Fig. 4B). The U7 snRNP binding site and 3 '-flanking region, however, are different from both the H3-614 and H3-615 genes (Fig. 4B).

The Sall site conserved in all other mouse histone $\mathrm{H} 3$ genes and used for $\mathrm{S} 1$ mapping of these genes (Wang et al. 1996; Graves et al. 1985) is missing from the $\mathrm{H} 3-616$ gene because of a single base change. Thus, to determine whether the H3616 gene was expressed, we labeled the gene at the $5^{\prime}$ end of the EagI site at codon 88 . When the histone H3-616 probe was hybridized to total cell RNA, two fragments were protected. One (267 nucleotides) mapped to the ATG codon and results from protection by a number of different histone mRNAs. The minor protected fragment (280 nucleotides) mapped to the $5^{\prime}$ end of the mRNA expressed from the H3-616 gene (Fig. 4C, lanes 1,4$)$. The $5^{\prime}$ end is located $\sim 25$ nucleotides from a TATAA sequence, consistent with this being the start site of transcription (Fig. 4A). The H3-616 gene encodes $\sim 6 \%$ of the histone $\mathrm{H} 3$ mRNA, a lower amount than encoded by the H3614 and H3-615 genes, which together encode $\sim 30 \%-35 \%$ of the histone $\mathrm{H} 3 \mathrm{mRNA}$ (Graves et al. 1985b). To demonstrate the difference in expression levels, probes for the H3-614 gene, labeled at the Sall site, were used together with the H3-616 probe. The H3-614 probe protects fragments of 180 and 220 nucleotides. The two probes were mixed and hybridized to total RNA from mouse myeloma cells. The four expected protected fragments were seen (Fig. 4C, lanes $5,6)$. The fragments mapping to the initiation codon $\left(\mathrm{H}_{\mathrm{M}}\right)$ were of similar intensity with each probe, whereas the specific fragment derived from the H3-616 gene was much less intense than the fragment derived from the H3-614 gene, demonstrating that the H3-616 gene was expressed at a low level relative to the H3-614 and H3-615 genes. Because the H3-614, H3-615, and H3-616 genes all have nearly identical 3'untranslated regions, it was not possible to unambiguously detect the $3^{\prime}$ end of the H3-616 mRNA.

\section{The Histone H2a Genes}

There were four histone $\mathrm{H} 2 \mathrm{a}$ genes present in this cluster. Two of these, H2a-614 and H2a-615, encode the H2a.2 protein (Hurt et al. 1989) and make up $-30 \%-35 \%$ of the histone H2a mRNA 
WANG ET AL.
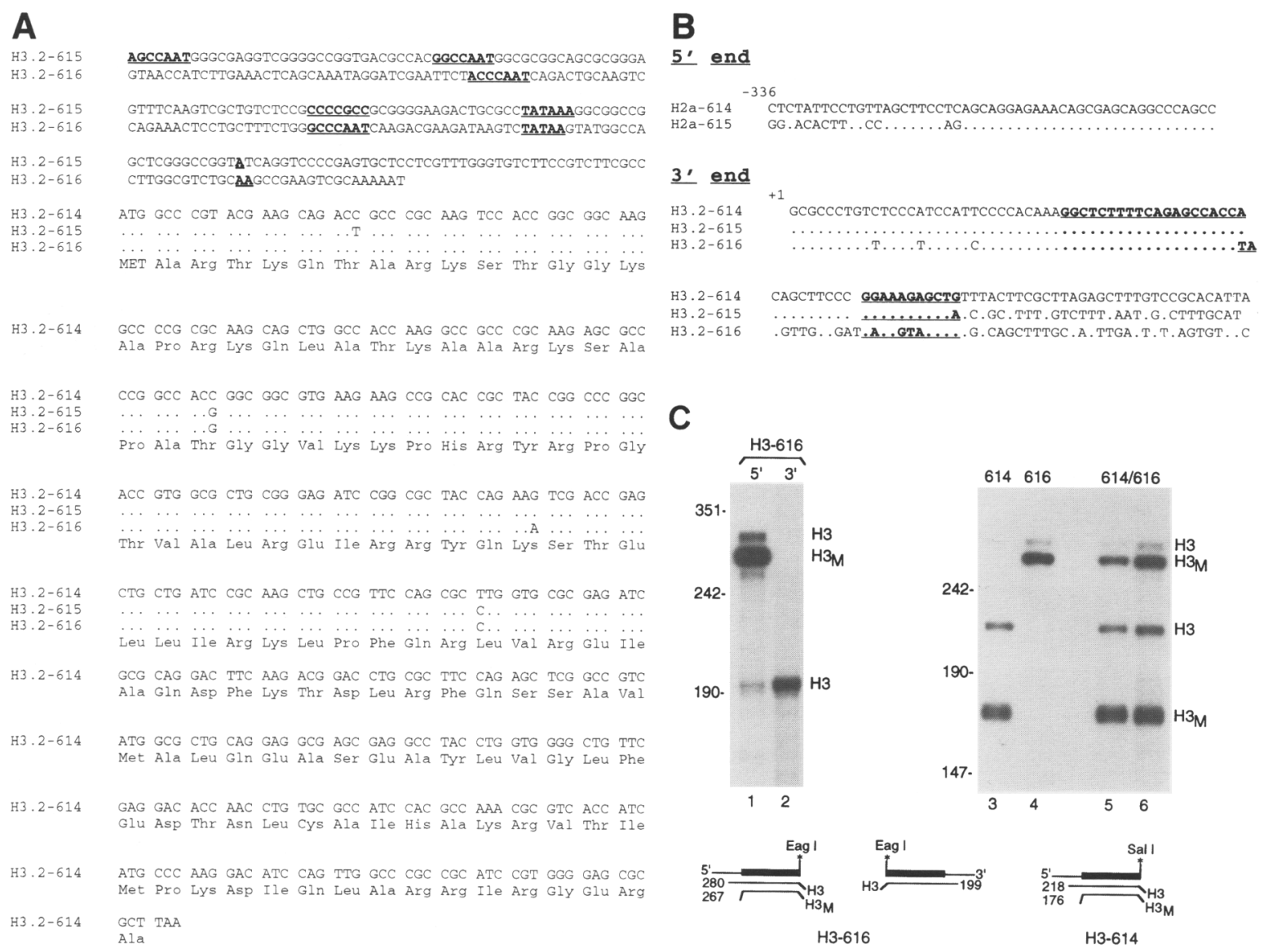

Figure 4 Structure and expression of the histone $\mathrm{H} 3$ genes. (A) Sequences of the histone $\mathrm{H} 3-614, \mathrm{H} 3-615$, and $\mathrm{H} 3-616$ genes. The promoters of the H3-615 (614) and H3-616 genes are compared, and the start site of transcription, the TATAA box, and CCAAT boxes are underlined. Where the three genes are identical in the coding region, only the $\mathrm{H} 3-614$ sequence is shown. (B) The $5^{\prime}$-flanking region of the $\mathrm{H} 2 \mathrm{a}-614$ and $\mathrm{H} 2 \mathrm{a}-615$ genes are compared around the point of divergence that is 323 nucleotides from the transcription start site, demonstrating the abrupt end of the region of identity. The 3'-flanking regions of the H3-614, H3-615, and H3-616 genes are compared from the end of the coding region to the region of divergence past the U7 snRNP-binding site. The conserved stem-loop at the end of the mRNA and the U7 snRNP-binding site are underlined. (C) Expression of the H3-614 (615) and H3-616 genes. To map the 5' end of the H3-616 mRNA the H3-616 gene was labeled at the $5^{\prime}$ end of the Eagl site (lanes 1,4) or the $3^{\prime}$ end of the Eagl site (lane 2) and the probe hybridized to 2.5 (lane 5) or 5 (lanes $1-4,6) \mu \mathrm{g}$ of total cell RNA from mouse myeloma cells. The hybrids were treated with $\mathrm{S} 1$ nuclease and the nuclease-resistant fragments were resolved by electrophoresis on $6 \%$ polyacrylamide/7 $\mathrm{M}$ urea gels and detected by autoradiography. The H3-614 gene was labeled at the $5^{\prime}$ end of the Sall site at codon 58 , and this probe was used to analyze the same RNA samples (lane 3). (Lanes 5,6) Two $5^{\prime}$ labeled probes were mixed prior to hybridization.

(Graves et al. 1985b). The other two H2a genes, $\mathrm{H} 2 \mathrm{a}(\mathrm{A})-613$ and $\mathrm{H} 2 \mathrm{a}(\mathrm{B})-613$, are located immediately adjacent to each other with their 3 ' ends juxtaposed. We predict that the primary transcripts from these genes overlap, because the U7 snRNP-binding sites are only 20 nucleotides apart (Fig. 5A). Each of these genes encodes a protein similar to the $\mathrm{H} 2 \mathrm{a} .2$ protein, with the 4 amino acid differences characteristic of H2a.2 (shown in boldface type in Fig. 5A). However, their carboxyl termini differ from each other and from other H2a proteins. Thus, each of these genes encodes an $\mathrm{H} 2 \mathrm{a} .2$ protein variant that has not been described previously.

By use of $S 1$ nuclease protection assays with the $\mathrm{H} 2 \mathrm{a}(\mathrm{A})-613$ gene labeled at the Accl site and the H2a(B)-613 gene labeled at the Narl site as probes, we identified mRNAs expressed from 
A

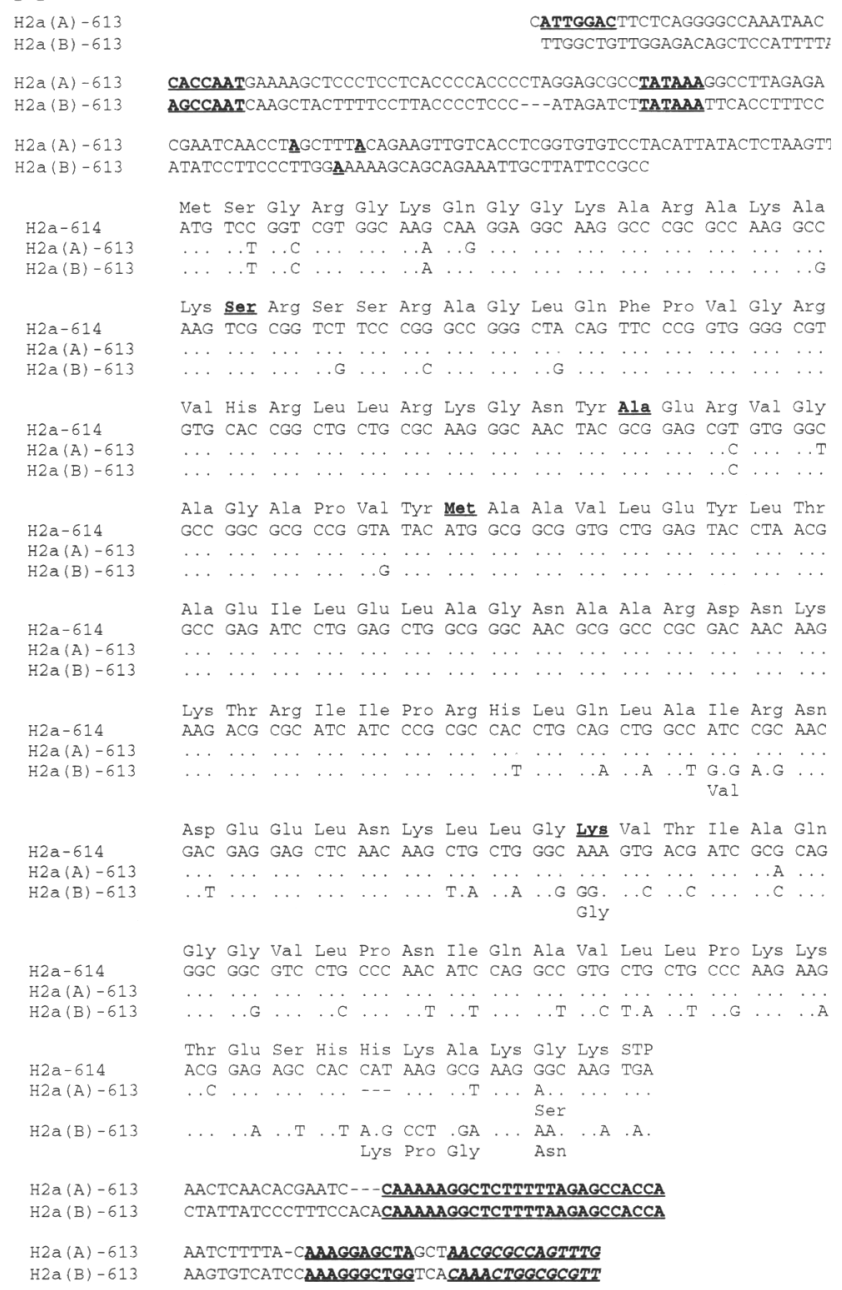

B
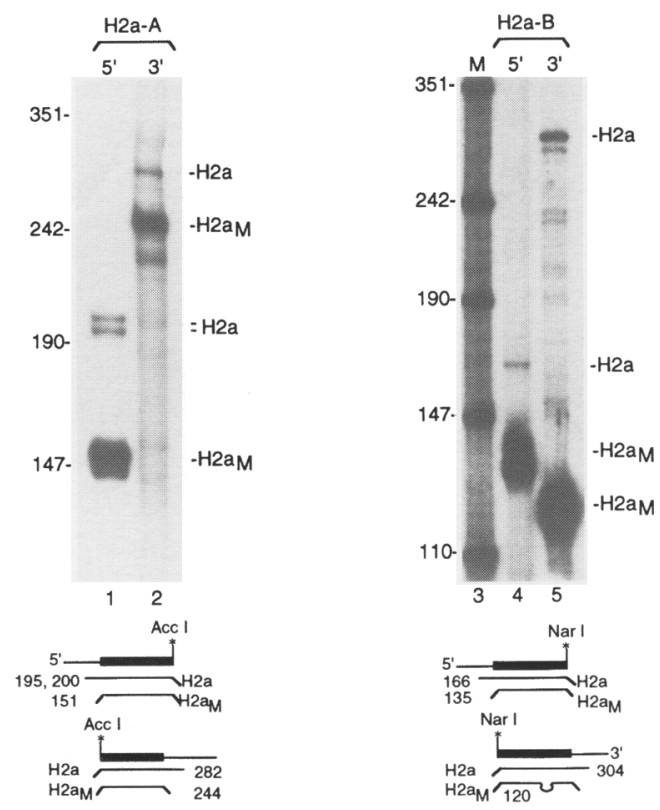

Figure 5 Structure and expression of the $H 2 a$ genes. $(A)$ The sequences of the $H 2 a-614, H 2 a(A)-613$, and $\mathrm{H} 2 \mathrm{~A}(\mathrm{~B})-613$ genes are compared, extending from the promoters of the gene to the region of overlap past the U7 snRNP-binding site. The overlapping sequences between these two genes are shown in bold italics. The transcription start site, the TATAA box, and CCAAT boxes are underlined as are the conserved stem-loop at the end of the mRNA and the U7 snRNP-binding site. (B) The expression of the $\mathrm{H} 2 \mathrm{a}(\mathrm{A})-613$ and $\mathrm{H} 2 \mathrm{a}(\mathrm{B})-613$ genes was determined by use of $\mathrm{S} 1$ nuclease mapping. The H2a-A gene was labeled at the $5^{\prime}$ end (lane 1 ) or $3^{\prime}$ end (lane 2) of the Accl site, and the H2a-B gene was labeled at the 5' end (lane 4) or the 3' end (lane 5) of the Narl site. The probes were hybridized with $5 \mu \mathrm{g}$ of total RNA from mouse myeloma cells and the protected fragments resolved by gel electrophoresis and detected by autoradiography.

each of these genes (Fig. 5B). Specific fragments mapping to the $3^{\prime}$ end and the $5^{\prime}$ end of the two histone mRNAs were mapped. The level of expression of both of these genes was very low. The $\mathrm{H} 2 \mathrm{a}(\mathrm{A})-613$ gene protects two fragments; the major one $\left(\mathrm{H} 2 \mathrm{a}_{\mathrm{M}}\right)$ derived from the H2a-614 and H2a-615 mRNA (151 nucleotides in the $5^{\prime}$ map and 244 nucleotides in the $3^{\prime}$ map), and the minor fragment $\left(\mathrm{H} 2 \mathrm{a}, 200\right.$ nucleotides in the $5^{\prime}$ map and 282 in the $3^{\prime}$ map) protects the $\mathrm{H} 2 \mathrm{a}(\mathrm{A})-613$ mRNA. Note that because only the H2a-614 and
H2a-615 genes contain an AccI site, which is absent in all of the histone H2a genes from chromosome 13, only these two mRNAs are protected to give the $\mathrm{H}_{2} \mathrm{a}_{\mathrm{M}}$ fragment. Thus, the expression of the H2a(A)-613 gene is much less than the closely linked H2a-614 and H2a-615 genes. There are two transcription start sites in the $\mathrm{H} 2 \mathrm{a}(\mathrm{A})-613$ gene, $\sim 5$ nucleotides apart, corresponding to two A's located 22 and 27 nucleotides from the TATAA box (Fig. 5B, lane 1).

The H2a(B)-613 gene is also expressed at a 
low level. Use of the NarI site, which is present in the H2a-614 and H2a-615 genes as well as the $\mathrm{H} 2 \mathrm{a}$ genes on chromosome 13 , generated two protected fragments with each probe (Fig. 5B, lanes 4,5). The major $5^{\prime}$ fragment $\left(\mathrm{H} 2 \mathrm{a}_{\mathrm{M}}, 135\right.$ nucleotides) maps to the AUG codon, whereas the minor fragment ( $\mathrm{H} 2 \mathrm{a}, 166$ nucleotide) maps to the start site of transcription of the $\mathrm{H} 2 \mathrm{a}(\mathrm{B})-613$ mRNA (Fig. 5B, lane 4). The major fragment $\left(\mathrm{H} 2 \mathrm{a}_{\mathrm{M}}\right)$ from the $3^{\prime}$ labeled probe is only 120 nucleotides, and maps to the cluster of nucleotide changes unique to the $\mathrm{H} 2 \mathrm{a}(\mathrm{B})-613$ gene at amino acids 87 and 88 (Fig. 5B, lane 5). The minor 304-nucleotide fragment $(\mathrm{H} 2 \mathrm{a})$ maps to the end of the $\mathrm{H} 2 \mathrm{a}(\mathrm{B})-613$ mRNA, bearing in mind that the H2a-614 and $\mathrm{H} 2 \mathrm{a}-615$ genes account for $-30 \%$ of the H2a mRNA and the $\mathrm{H} 2 \mathrm{a}(\mathrm{A})-613$ and $\mathrm{H} 2 \mathrm{a}(\mathrm{B})-613$ genes each account for no more than $5 \%$ of the H2a mRNA. Given this low level of expression, it is possible that these two genes are not transcribed simultaneously, as there would then presumably be a collision between the two RNA polymerases. Alternatively, it is possible that the close proximity of the genes reduces the expression of the genes due to interference between two elongating RNA polymerase molecules.

\section{The Histone $\mathrm{H} 2 \mathrm{~b}$ and $\mathrm{H} 4$ Genes}

Two H2b genes, $\mathrm{H} 2 \mathrm{~b}-616$ and $\mathrm{H} 2 \mathrm{~b}-613$, are present, one at each end of the cluster. Each of these genes encodes an $\mathrm{H} 2 \mathrm{~b}$ protein, similar in sequence to the reported mammalian $\mathrm{H} 2 \mathrm{~b}$ protein sequence. Note that the predicted amino acid sequence of each of the seven mouse $\mathrm{H} 2 \mathrm{~b}$ genes that we have isolated (Liu et al. 1987; Brown et al. 1996) is different. The consensus sequence from this sequence agrees with the reported mammalian $\mathrm{H} 2 \mathrm{~b}$ protein sequence, which has heterogeneity in at least two positions (Ohe et al. 1979). On the basis of the results from cloned $\mathrm{H} 2 \mathrm{~b}$ genes, the mouse $\mathrm{H} 2 \mathrm{~b}$ proteins are a mixture of at least seven closely related polypeptides.

The promoters of the $\mathrm{H} 2 \mathrm{~b}$ genes have a structure similar to the other mouse (and metazoan) H2b genes (Harvey et al. 1982; Liu et al. 1987; Ito et al. 1989; Bell et al. 1992). There are three elements in the proximal promoter: a TATAA box, a CCAAT box, and an octamer sequence, which binds Oct-1 (Fletcher et al. 1987; Das and Herr 1993) located between the CCAAT and TATAA boxes. The octamer sequence is present in all known metazoan $\mathrm{H} 2 \mathrm{~b}$ genes and is necessary for expression of the genes (LaBella et al. 1988; Sturm et al. 1988; Bell et al. 1992). Although the CCAAT, octamer, and TATAA boxes are identically spaced from each other in the $\mathrm{H} 2 \mathrm{~b}-613$ and H2b-616 genes, there are no other similarities between these promoters.

The mRNA expressed from the $\mathrm{H} 2 \mathrm{~b}-616$ gene was detected by S1 nuclease mapping with the gene labeled at the EcoRI site at codon 62 as a probe. Because the EcoRI site is not present in any of the other $\mathrm{H} 2 \mathrm{~b}$ genes we have isolated, there was a single protected fragment with each probe, which extended to the end of the mRNA (Fig. 6B, lanes 3,4$)$. To estimate the level of expression of the H2b-616 gene, we analyzed the same RNA samples with the H3-616 gene labeled at the 5' end of the EagI site to the same specific activity (Fig. 6B, lane 2). The H2b-616 and the H3-616 genes were expressed at a similar level (Fig. 6B, lanes 1,3).

The $\mathrm{H} 2 \mathrm{~b}-613$ gene was $<250$ nucleotides from the $\mathrm{H} 2 \mathrm{a}(\mathrm{A})-613$ gene, and their $5^{\prime}$ ends are juxtaposed. This is an arrangement that is very common in the mouse $\mathrm{H} 2 \mathrm{a}$ and $\mathrm{H} 2 \mathrm{~b}$ genes on chromosome 13 (Liu et al. 1987; Brown et al. 1996) and in the $\mathrm{H} 2 \mathrm{a}-\mathrm{H} 2 \mathrm{~b}$ genes in other species (Grandy and Dodgson 1987). The distance between these genes is essentially identical with the five $\mathrm{H} 2 \mathrm{a}-\mathrm{H} 2 \mathrm{~b}$ pairs from mouse chromosome 13 (Brown et al. 1996; Liu et al. 1987; Brown et al. 1996). The H2b-613 gene encodes a complete H2b protein, although it lacks the stem-loop normally present at the 3 ' end of all replication dependent histone mRNAs. There is a sequence with similarity to the stem-loop present at the normal location, -50 nucleotides from the stop codon (underlined in Fig. 6A), suggesting that this gene previously contained a stem-loop sequence.

Despite the fact that the $\mathrm{H} 2 \mathrm{~b}-613$ gene lacks a stem-loop, this gene was clearly expressed. Total RNA from mouse myeloma cells or from newborn mice was analyzed by $S 1$ nuclease mapping with the H2b-613 gene labeled at the $3^{\prime}$ end of the $N$ coI site as a probe (Fig. 6B, lanes 9,10). The probe used extended to the Sall site 313 nucleotides past the stop codon. The NcoI-SalI fragment was cloned into pGEM5zf, and the resulting clone digested with $N c o$ I and 3'-end-labeled at the NcoI site. Any RNAs extending past the SalI site would result in a 528 nucleotide protected fragment. There clearly is a protected fragment of the appropriate size indicating that the $\mathrm{H} 2 \mathrm{~b}-613$ gene is expressed (Fig. 6B, lanes 9,10). There was 

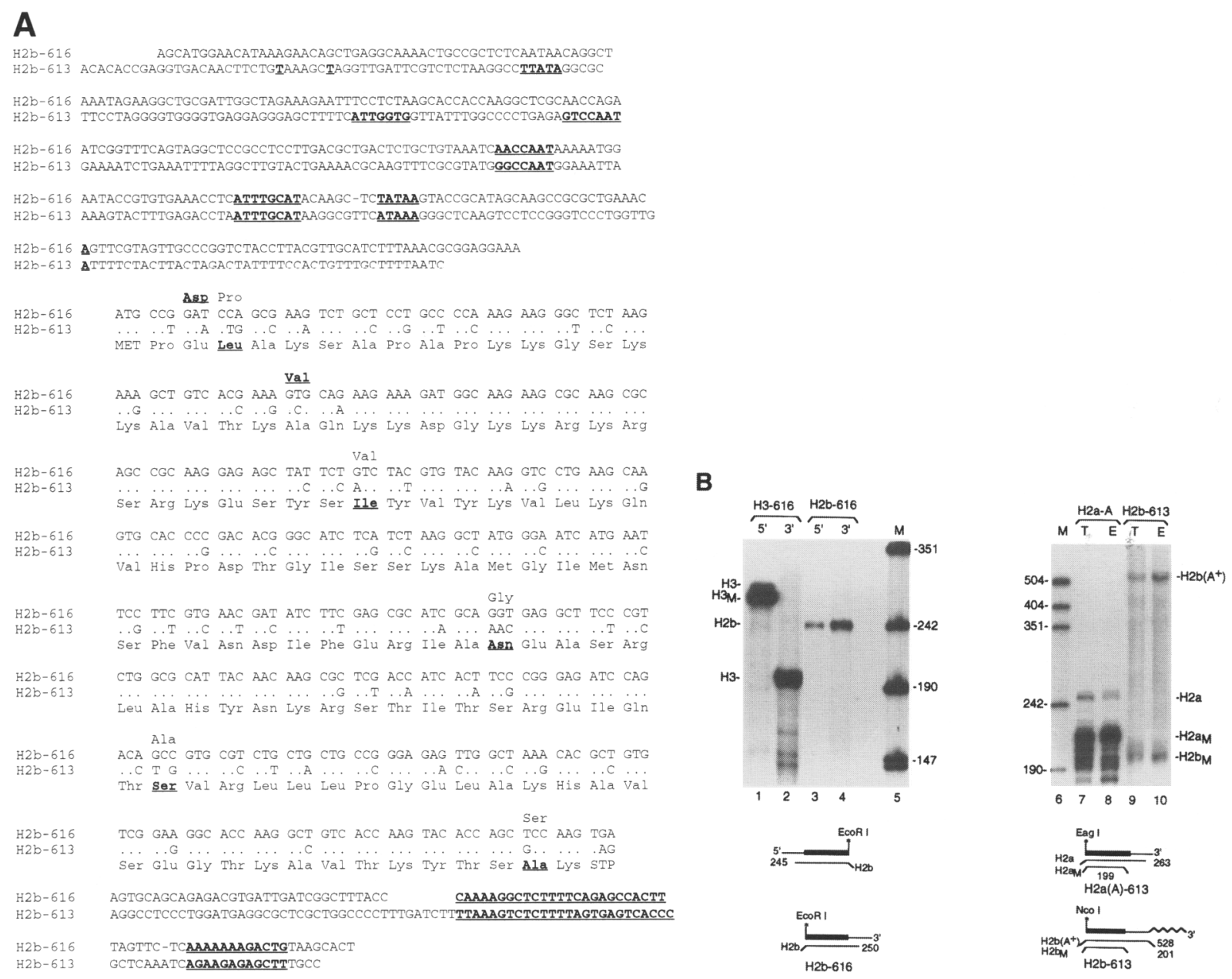

Figure 6 Structure and expression of the H2b genes. (A) Sequences of the H2b-613 and H2b-616 gene. Where the genes differ in amino acid sequence, the amino acid in bold is the one that is not found in $\mathrm{H} 2 \mathrm{~b}$ consensus sequence. The promoters are compared with the Oct-1, CCAAT, and TATAA sequences aligned. The 3 '-flanking regions are shown with the conserved stem-loop at the end of the MRNA and the U7 SnRNP-binding site underlined in the $\mathrm{H} 2 \mathrm{~b}-616$ gene. The $\mathrm{H} 2 \mathrm{~b}-613$ gene lacks these sequences, but there are possible remnants of each of these sequences that are underlined. (B) The expression of the $\mathrm{H} 2 \mathrm{~b}$ genes was determined by $\mathrm{S} 1$ nuclease mapping. The H2b-616 gene was labeled at the $5^{\prime}$ end (lane 3) or the $3^{\prime}$ end (lane 4) of the EcoRl site at codon 62. The H3-616 gene labeled at the $5^{\prime}$ end (lane 1) or $3^{\prime}$ end (lane 2) of the Eagl site at the same specific activity was used as a control. These probes were hybridized with $5 \mu \mathrm{g}$ of total RNA from mouse myeloma cells (lanes 1-4). The H2b-613 gene was labeled at the $3^{\prime}$ of the Ncol site (lanes 9,10) and the probe extended to the Sall site in the $3^{\prime}$-untranslated region. This probe was hybridized with $30 \mu \mathrm{g}$ of total RNA from adult testis (lane 9) or neonatal mice (lane 10). As a control for the level of expression, the $\mathrm{H} 2 \mathrm{a}(\mathrm{A})-613$ gene was labeled to the same specific activity at the $3^{\prime}$ end of the Eagl site (lanes 7,8 ). This probe was hybridized with $5 \mu \mathrm{g}$ of total RNA from testis (lane 7) or $5 \mu \mathrm{g}$ of total RNA from neonatal mice (lane 8). (Lanes 5,6) Marker pUC18 digested with Hpall.

also a fragment of 201 nucleotides mapping to the stop codon. This is the result of protection of a minority of the other H2b mRNAs up to the stop codon. The 528-nucleotide fragment is from a polyadenylated mRNA (not shown), suggesting that this gene is expressed as a polyadenylated mRNA ending at a polyadenylation signal located at an unknown distance $3^{\prime}$ of the coding region. The same pattern of expression was observed in both RNA from neonatal mice and mouse testis, a tissue that often expresses polyadenylated histone mRNAs (Challoner et al. 1989; Moss and Orth 1993; Moss et al. 1994). The level of expression of the H2b-613 gene was comparable to the expression of the $\mathrm{H} 2 \mathrm{a}(\mathrm{A})-613$ gene analyzed with the same RNA samples (Fig. 6B, 


\section{WANG EI AL.}

lanes 7,8). The H2b-613 gene was also expressed in a number of adult mouse tissues (data not shown) at a similarly low level. Thus, both of these $\mathrm{H} 2 \mathrm{~b}$ genes are expressed at low levels, contributing only a minority of the histone $\mathrm{H} 2 \mathrm{~b}$ mRNA.

There is a single $\mathrm{H} 4$ gene present in this cluster. This gene was first identified by Birnstiel and co-workers (Seiler-Tuyns and Birnstiel 1981). We identified the orientation and precise location of this gene by PCR with a primer from the $5^{\prime}$ flanking region of the adjacent H3-616 gene and with sense and antisense primers from the coding region of the histone $\mathrm{H} 4$ gene. Only the antisense fragment from the $\mathrm{H} 4$ gene gave a product that was sequenced and contained the $\mathrm{H} 4$ gene, indicating that the H3-616 gene and $\mathrm{H} 4$ gene are oriented in opposite directions. In agreement with the results of Seiler-Tuyns and Birnstiel (1981) in mouse $\mathrm{L}$ cells, this $\mathrm{H} 4$ gene is expressed at a very low level, contributing only a tiny fraction of the total mouse histone $\mathrm{H} 4$ mRNA (not shown). Thus, the great majority of the histone $\mathrm{H} 4$ mRNA is derived from the nine histone $\mathrm{H} 4$ genes on mouse chromosome 13.

The 10 histone genes on chromosome 3 encode a significant fraction of the histone $\mathrm{H} 3$ and $\mathrm{H} 2 \mathrm{a}$ mRNAs but only a small fraction of the $\mathrm{H} 2 \mathrm{~b}$ and $\mathrm{H} 4$ mRNAs. There were no histone $\mathrm{H} 1$ genes present in this cluster.

\section{DISCUSSION}

The core histone proteins must be produced in equimolar amounts during $S$ phase as the newly replicated DNA is packaged into nucleosomes. The high demand for histone mRNA to synthesize the $10^{8}$ histone proteins required in each $\mathrm{S}$ phase presumably requires multiple copies of the histone genes. In addition, there are a number of nonallelic variants of the core histone proteins, which are present in all vertebrates (Zweidler 1984). Whether these variants are functionally significant is not known.

There are changes in the relative proportions of the different histone variants, both in different tissues and at different developmental stages (Zweidler 1984). The replacement histone H3.3 is synthesized constitutively and accumulates to high levels in the chromatin of terminally differentiated cells as they age (Zweidler 1984). The H3.3 protein is encoded by genes that contain introns and produce polyadenylated mRNAs (Brush et al. 1985; Wells and Kedes 1985), and these mRNAs are expressed constitutively. The histone $\mathrm{H} 3.2$ and $\mathrm{H} 2 \mathrm{a} .2$ proteins have been classified as partially replication dependent (Zweidler 1984), as they accumulate at higher levels in some terminally differentiated cells, although they are synthesized solely in $S$ phase. Sittman and co-workers showed that the accumulation of the $\mathrm{H} 3.2$ and $\mathrm{H} 2 \mathrm{a} .2$ proteins in terminally differentiating erythroleukemic cells is the result of preferential expression of the $\mathrm{H} 2 \mathrm{a}-614$ and $\mathrm{H} 3-$ 614 (and presumably also the H3-615 and H2a615) genes during the last $S$ phase (Brown et al. 1985; Brown et al. 1988). They postulated that this accumulation might be a result of shutting off expression of histone genes on chromosome 13 (Brown et al. 1988) as cells terminally differentiate. Thus, it is somewhat surprising that the histone gene cluster on chromosome 3 does not contain any highly expressed histone genes for the other core histones. The histone $\mathrm{H} 4$ and $\mathrm{H} 2 \mathrm{~b}$ mRNAs are almost entirely derived (>90\%) from the genes on mouse chromosome 13 . The preferential expression of the H3-614 and H2a-614 (and H3-615 and H2a-615) genes must account for the accumulation of the H3.2 and H2a.2 protein variants as cells terminally differentiate. The $\mathrm{H} 2 \mathrm{~b}$ and $\mathrm{H} 4$ proteins, however, as well as the histone $\mathrm{H} 1$ proteins, continue to be produced primarily from mRNAs encoded on chromosome 13.

The H3.2 protein is the major histone $\mathrm{H} 3$ variant in rodents (Zweidler 1984), although it is a minor variant in cows (Marzluff et al. 1972; Patthy and Smith 1975) and humans (Wu and Bonner 1981). Of the nine histone $\mathrm{H} 3$ genes on mouse chromosome 13, five encode histone H3.2 and four encode histone H3.1 (Wang et al. 1996). The predominance of the H3.2 protein variant caused by the expression of $\sim 35 \%$ of the histone H3 mRNA from chromosome 3, all of which encodes the $\mathrm{H} 3.2$ variant. In other mammals there is a much higher proportion of the H3.1 than H3.2 protein. It is likely either that the genes on the minor cluster in other mammals encode H3.1 proteins, or that all the genes on the major cluster encode histone H3.1 proteins, accounting for the change in relative proportions of the protein variants in different mammals.

All of the histone $\mathrm{H} 2 \mathrm{a}$ genes that have been cloned from mouse chromosome 13 encode the H2a.1 protein (Liu et al. 1987; Kosciessa and Doenecke 1989; Gruber et al. 1990; Brown et al. 1996). Thus, it is very likely that the H2a.2 protein is exclusively encoded by the genes on chromosome 3 . The $\mathrm{H} 2 \mathrm{a} .2$ protein makes up $>30 \%$ of 


\section{MOUSE HISTONE GENE CLUSTER ON CHROMOSOME 3}

the $\mathrm{H} 2 \mathrm{a}$ protein in most mouse tissues, consistent with the high level of expression of the genes on chromosome 3 . A number of human $\mathrm{H} 2 \mathrm{a}$ mRNAs have been characterized. The four human H2a.1 mRNAs each are derived from human chromosome 6 (Mannironi et al. 1994). The human H2a.2 mRNA, is derived from human chromosome 1 (Mannironi et al. 1994). The single human H2a.2 mRNA, like the mouse H2a.2 mRNA encoded by the $\mathrm{H} 2 \mathrm{a}-614$ and $\mathrm{H} 2 \mathrm{a}-615$ genes, was expressed at a higher level than the other human H2a mRNAs, encoding $35 \%-45 \%$ of the $\mathrm{H} 2 \mathrm{a}$ mRNA (Mannironi et al. 1994). Thus, the overall organization and expression level of the individual histone genes has probably been conserved between mice and men.

The H2a-614 and H3-614 genes have been duplicated in this cluster. The region of near identity extends for $>2.1 \mathrm{~kb}$, ending precisely after the U7 snRNP binding site $3^{\prime}$ of the H3-614 gene and starting 323 nucleotides $5^{\prime}$ of the $\mathrm{H} 2 \mathrm{a}$ genes. The $\mathrm{H} 2 \mathrm{a}-614$ gene has recently been found expressed in testis as a polyadenylated mRNA utilizing a cryptic polyadenylation site that overlaps with the U7 snRNP-binding site (Moss et al. 1994). This sequence is identical in the H2a-615 gene, which is presumably also expressed as a polyadenylated mRNA in testis. Thus, in addition to providing a large fraction of the H2a mRNA in somatic cells, this gene pair expresses a unique transcript in the testis. These genes also encode most of the $\mathrm{H} 2 \mathrm{a}$ and $\mathrm{H} 3$ mRNA present in mouse oocytes, and early cleavage embryos (Graves et al. 1985a).

The two H2a.2-like genes, H2a(A)-613 and $\mathrm{H} 2 \mathrm{a}(\mathrm{B})-613$, and the $\mathrm{H} 2 \mathrm{~b}-613$ gene each encode $\mathrm{a}$ very small amount of mRNA. Although these three genes are clearly functional, it is not at all clear whether these $\mathrm{H} 2 \mathrm{a}$ protein variants are important. They may represent genes that have accumulated mutations in the protein but have still remained functional. The $\mathrm{H} 2 \mathrm{~b}-613$ gene also encodes an $\mathrm{H} 2 \mathrm{~b}$-like protein that differs significantly from other mouse histone $\mathrm{H} 2 \mathrm{~b}$ proteins. Moreover, all the mRNAs from this gene are polyadenylated, as the stem-loop sequence is missing. We did not see high-level expression of this gene in a number of different mouse tissues (Z.F. Wang and W.F. Marzluff, unpubl.), including testis (Fig. 6B), reducing the possibility that this is a tissue-specific gene.

There are closely linked histone $\mathrm{H} 2 \mathrm{a}$ and $\mathrm{H} 2 \mathrm{~b}$ genes encoded on human chromosome 1 . It is possible that these genes are orthologous to the
H2b-613 and H2a-613 genes described here, particularly because the human $\mathrm{H} 2 \mathrm{~b}$ gene also expresses a polyadenylated mRNA as well as an RNA ending in a stem-loop (Collart et al. 1991, 1992). The function of the polyadenylated RNA is not clear. Normally, it is produced in small amounts and increases when the normal histone 3 '-end formation is inactive, in terminally differentiated cells and in cells in which DNA replication has been inhibited (Collart et al. 1991). The predicted amino acid sequence of the human $\mathrm{H} 2 \mathrm{~b}$ protein differs from the $\mathrm{H} 2 \mathrm{~b}-616$ protein, and only one of the amino acids (Val-39) unique to the H2b-613 gene is conserved in the human gene on chromosome 1. The linked human $\mathrm{H} 2 \mathrm{a}$ gene has not been completely sequenced so it is not known whether it encodes the same protein as the mouse $\mathrm{H} 2 \mathrm{a}(\mathrm{A})-613$ gene. Also, it is not clear whether there is an additional $\mathrm{H} 2 \mathrm{a}$ gene present in humans.

\section{Evolution of the Histone Genes on Chromosome 3}

The almost complete identity between the H3614 and H3-615 genes and the $\mathrm{H} 2 \mathrm{a}-614$ and $\mathrm{H} 2 \mathrm{a}-$ 615 genes might indicate that there has been a very recent duplication event involving this region of chromosome 3 . At least one line of evidence argues against that interpretation, however. Duplication of one of the most highly expressed $\mathrm{H} 3$ and $\mathrm{H} 2 \mathrm{a}$ genes but not of any $\mathrm{H} 2 \mathrm{~b}$ or $\mathrm{H} 4$ genes would likely upset the stoichiometric relationship among the mRNA and protein levels of the four core histone (although this argument does presuppose that equal production of the four core histones is important, and that there is no feedback mechanism for autoregulation of histone expression levels).

An alternative mechanism to explain the high level of sequence identity among these genes, as well as between the $614 / 615$ pairs and the H3-616 gene and between the two H2a-613 genes, is gene conversion. Clearly, some histone genes on chromosome 13 have been involved in gene conversion (Liu et al. 1987; Brown et al. 1996; Wang et al. 1996), and much of the difference between the chromosome $3 \mathrm{H} 3$ genes compared to the chromosome $13 \mathrm{H} 3$ genes appears to be caused by gene conversion among the chromosome 13 genes (Debry and Marzluff 1994). Differences in the promoter region between the H3-616 gene compared to the H3-614/H3-615 pair strongly suggests that gene conversion of the coding region, and not a recent duplication, is 


\section{WANG ET AL.}

responsible for the extreme similarity among these three genes. These data agree with the conclusion that gene conversion is very rare between the histone genes on chromosomes 3 and 13 (Debry and Marzluff 1994).

The two H2a-613 genes also show an interesting pattern that is likely attributable to gene conversion. Within the first five codons, the $\mathrm{H} 2 \mathrm{a}(\mathrm{A})-613$ and $\mathrm{H} 2 \mathrm{a}(\mathrm{B})-613$ genes share three silent differences compared to $\mathrm{H} 2 \mathrm{a}-614$. For most of the remaining sequence, however, the $\mathrm{H} 2 \mathrm{a}(\mathrm{A})$ 613 gene is virtually identical to $\mathrm{H} 2 \mathrm{a}-614$, with only three silent differences over 113 contiguous codons. Over that same stretch, the $\mathrm{H} 2 \mathrm{a}(\mathrm{B})-613$ gene has a total of 34 differences, including 2 replacement differences. The implication is that the $\mathrm{H} 2 \mathrm{a}-614$ gene may have recently converted the $\mathrm{H} 2 \mathrm{a}(\mathrm{A})-613$ gene over most of the coding sequence.

In contrast, the two $\mathrm{H} 2 \mathrm{~b}$ genes on chromosome 3 differ greatly at the nucleotide sequence level, although they encode quite similar proteins, suggesting that these two genes have not been involved in a recent gene conversion event. It is certainly not clear whether all of the histone genes are essential, and in particular, whether the different minor protein variants encoded by the $\mathrm{H} 2 \mathrm{a}$ and $\mathrm{H} 2 \mathrm{~b}$ genes are physiologically important.

Although we cannot unequivocally rule out the presence of additional histone genes on mouse chromosome 3 located farther than $25 \mathrm{~kb}$ from any of these genes, in situ hybridization experiments with coding region probes clearly show that most of the core histone genes are present on chromosome 13 (W.F. Marzluff and J. Hozier, unpubl.). There are about nine copies of each of the core histone genes on chromosome 13 (Wang et al. 1996), and the additional two to four copies present on chromosome 3 probably account for the complete complement of the replication-depen-dent mouse histone genes.

\section{METHODS}

\section{Isolation of $\mathrm{Pl}$ and Phage $\lambda$ Clones}

A series of overlapping P1 clones (P0, P1, P2, and P3) was isolated by Genome Systems (St. Louis, MO) by PCR with a set of primers flanking the H3-614 gene. After ordering these P1 clones, the end of clone P0 was sequenced and a set of primers were designed to isolate a second set of P1 clones (P91 and P92). Because both clones ended in the same region, a probe was synthesized by use of $\mathrm{T} 7 \mathrm{RNA}$ polymerase from the end of clone P92, which extended the furthest from one end of the histone cluster, and this probe was used to screen a mouse genomic library in $\lambda F I X I I$. A single phage that extended this cluster an additional $12 \mathrm{~kb}$ was isolated in this screen.

\section{Mapping of the PI Clones}

Probes to the ends of each of the P1 clones were synthesized by use of SP6 or T7 RNA polymerase and these probes were used to orient and order the clones by Southern blotting. The size of the inserts was estimated after digestion with NotI, which cuts at the junction of the vector and the insert. There were no Notl sites in any of the inserts. The position of each gene was determined by Southern blotting with probes from each of the core histone genes. Specific probes from the 3'-flanking region of the H3-614 and H3-615 genes, and the $5^{\prime}$-flanking region of the $\mathrm{H} 2 \mathrm{a}-614$ and $\mathrm{H} 2 \mathrm{a}-615$ genes were used in Southern blots to determine the orientation of these two duplicated genes.

\section{In Situ Hybridization}

Mouse metaphase spreads were prepared from cultured spleenocytes by use of a standard methanol/acetic acid fixation protocol. The following clones were used for FISH: P0, P3, P91, P92, and $\lambda 111$. Mapping was done as described in Wang et al. (this issue).

\section{DNA Sequencing}

The genes were subcloned in plasmid vectors and the sequences determined in the UNC DNA Sequencing Facility.

\section{S1 Nuclease Mapping}

Total RNA was prepared from cultured mouse myeloma cells or from neonatal mice (1 day old) and the transcripts detected by $\mathrm{S} 1$ nuclease mapping essentially as described (Graves et al. 1985; Wang et al., this issue).

\section{ACKNOWLEDGMENTS}

This work was supported by National Institutes of Health (NIH) grant GM 29832 to W.F.M. A.G.M. was supported by grant JFRA-570 from the American Cancer Society and NIH grant GM 53034. We thank Laura Livingstone and Jenifer Langdon of the UNC DNA Sequencing Facility for their help. The sequence data described in this paper have been submitted to the GenBank data library under the following accession numbers: H2b-613, H2a(A)-13, H2a(B)-613, U62673; H2a-614, H3-614, X16148; H2a-615, H3-615, U62674; H2b-616, H3-616, U62675.

The publication costs of this article were defrayed in part by payment of page charges. This article must therefore be hereby marked "advertisement" in accordance with 18 USC section 1734 solely to indicate this fact.

\section{REFERENCES}

Bell, J., B.R. Char, and R. Maxson. 1992. An octamer element is required for the expression of the alpha $\mathrm{H} 2 \mathrm{~B}$ 


\section{MOUSE HISTONE GENE CLUSTER ON CHROMOSOME 3}

histone gene during the early development of the sea urchin. Dev. Biol. 150: 363-371.

Birnstiel, M.L., M. Busslinger, and K. Strub. 1985. Transcription termination and 3' processing: The end is in site! Cell 41: 349-359.

Brown, D.T., S.E. Wellman, and D.B. Sittman. 1985. Changes in the levels of three different classes of histone mRNA during murine erythroleukemia cell differentiation. Mol. Cell Biol. 5: 2879-2886.

Brown, D.T., Y.-S. Yang, and D.B. Sittman. 1988. Histone gene switching in murine erythroleukemia cells is differentiation specific and occurs without loss of cell cycle regulation. Mol. Cell Biol. 8: 4406-4415.

Brown, V.D., Z.-F. Wang, A.S. Williams, and W.F. Marzluff. 1996. Structure of a cluster of mouse histone genes. Biochim. Biophys. Acta Gene Struct. Expression 1306: $17-22$.

Brush, D., J.B. Dodgson, O.R. Choi, P.W. Stevens, and J.D. Engel. 1985. Replacement variant histone genes contain intervening sequences. Mol. Cell Biol. 5: $1307-1317$.

Challoner, P.B., S.B. Moss, and M. Groudine. 1989. Expression of replication-dependent histone genes in avian spermatids involves an alternate pathway of mRNA 3'-end formation. Mol. Cell Biol. 9: 902-913.

Collart, D., A. Ramsey-Ewing, R. Bortell, J. Lian, J. Stein, and G. Stein. 1991. Isolation and characterization of a cDNA from a human histone $\mathrm{H} 2 \mathrm{~B}$ gene which is reciprocally expressed in relation to replication-dependent $\mathrm{H} 2 \mathrm{~B}$ histone genes during HL60 cell differentiation. Biochemistry 30: 1610-1617.

Collart, D., P.L. Romain, K. Huebner, S. Pockwinse, S. Pilapil, L.A. Cannizzaro, J.B. Lian, C.M. Croce, J.L. Stein, and G.S. Stein. 1992. A human histone H2B.1 variant gene, located on chromosome 1, utilizes alternative $3^{\prime}$ end processing. J. Cell Biochem. 50: 374-385.

Das, G. and W. Herr. 1993. Enhanced activation of the human histone $\mathrm{H} 2 \mathrm{~B}$ promoter by an Oct-1 variant generated by alternative splicing. J. Biol. Chem. 268: $25026-25032$.

Debry, R.W. and W.F. Marzluff. 1994. Selection on silent sites in the rodent $\mathrm{H} 3$ histone gene family. Genetics 138: 191-202.

Doenecke, D., W. Albig, H. Bouterfa, and B. Drabent. 1994. Organization and expression of $\mathrm{H} 1$ histone and H1 replacement histone genes. J. Cell Biochem. 54: $423-431$.

Fletcher, C., N. Heintz, and R.G. Roeder. 1987. Purification and characterization of OTF-1, a transcription factor regulating cell cycle expression of a human histone H2b gene. Cell 51: 773-781.
Grandy, D.K. and J.B. Dodgson. 1987. Structure and organization of the chicken $\mathrm{H} 2 \mathrm{~B}$ histone gene family. Nucleic Acids Res. 15: 1063-1080.

Graves, R.A., W.F. Marzluff, D.H. Giebelhaus, and G.A. Schultz. 1985a. Quantitative and qualitative changes in histone gene expression during early mouse embryo development. Proc. Natl. Acad. Sci. 82: 5685-5689.

Graves, R.A., S.E. Wellman, I.-M. Chiu, and W.F. Marzluff. 1985b. Differential expression of two clusters of mouse histone genes. J. Mol. Biol. 183: 179-194.

Gruber, A., A. Streit, M. Reist, P. Benninger, R. Böhni, and D. Schümperli. 1990. Structure of a mouse histone-encoding gene cluster. Gene 95: 303-304.

Harvey, R.P., A.J. Robins, and J.R. Wells. 1982. Independently evolving chicken histone $\mathrm{H} 2 \mathrm{~B}$ genes: Identification of a ubiquitous H2B-specific 5' element. Nucleic Acids Res. 10: 7851-7863.

Hurt, M.M., N. Chodchoy, and W.F. Marzluff. 1989. The mouse histone $\mathrm{H} 2 \mathrm{a} .2$ gene from chromosome 3 . Nucleic Acids Res. 17: 8876.

Ito, M., A. Sharma, A.S. Lee, and R. Maxson. 1989. Cell cycle regulation of $\mathrm{H} 2 \mathrm{~b}$ histone octamer DNA-binding activity in Chinese hamster lung fibroblasts. Mol. Cell Biol. 9: 869-873.

Jacob, E. 1976. Histone gene reiteration in the mouse. Eur. J. Biochem. 65: 275-284.

Kosciessa, U. and D. Doenecke. 1989. Nucleotide sequences of mouse histone genes $\mathrm{H} 2 \mathrm{~A}$ and H3.1. Nucleic Acids Res. 17: 8861.

LaBella, F., H.L. Sive, R.G. Roeder, and N. Heintz. 1988. Cell-cycle regulation of a human histone $\mathrm{H} 2 \mathrm{~b}$ gene is mediated by the H2b subtype-specific consensus element. Genes \& Dev. 2: 32-39.

Liu, T.-J., L. Liu, and W.F. Marzluff. 1987. Mouse histone $\mathrm{H} 2 \mathrm{a}$ and $\mathrm{H} 2 \mathrm{~b}$ genes; four functional genes and a pseudogene undergoing gene conversion with a closely linked functional gene. Nucleic Acids Res. 15: 3023-3039.

Mannironi, C., A. Orr, C. Hatch, D. Pilch, V. Ivanova, and $\mathrm{W}$. Bonner. 1994. The relative expression of human histone $\mathrm{H} 2 \mathrm{~A}$ genes is similar in different types of proliferating cells. DNA Cell Biol. 13: 161-170.

Marzluff, W.F. 1992. Histone 3' ends: Essential and regulatory functions. Gene Expression 2: 93-97.

Marzluff, W.F., L.A. Sanders, D.M. Miller, and K.S. McCarty. 1972. Two chemically and metabolically distinct forms of calf thymus histone F3. J. Biol. Chem. 247: 2026-2031.

Moss, S.B. and J.M. Orth. 1993. Localization of a spermatid-specific histone $2 \mathrm{~B}$ protein in mouse spermiogenic cells. Biol. Reprod. 48: 1047-1056. 


\section{WANG ET AL.}

Moss, S.B., R.A. Ferry, and M. Groudine. 1994. An alternative pathway of histone mRNA 3 ' end formation in mouse round spermatids. Nucleic Acids Res. 22: 3160-3166.

Ohe, Y., H. Hayashi, and K. Iwai. 1979. Human spleen histone H2b. Isolation and amino acid sequence. $J$. Biochem. 85: 615-624.

Patthy, L. and E.L. Smith. 1975. Histone III:VI. Two forms of calf thymus histone III. J. Biol. Chem. 250: $919-920$.

Seiler-Tuyns, A. and M.L. Birnstiel. 1981. Structure and expression in L-cells of a cloned $\mathrm{H} 4$ histone gene of the mouse. J. Mol. Biol. 157: 607-625.

Sturm, R.A., S. Dalton, and J.R.E. Wells. 1988.

Conservation of histone $\mathrm{H} 2 \mathrm{~A} / \mathrm{H} 2 \mathrm{~B}$ intergene regions: A role for the $\mathrm{H} 2 \mathrm{~B}$ specific element in divergent transcription. Nucleic Acids Res. 16: 8571-8586.

Triputti, P., B.S. Emanuel, C.M. Croce, L.G. Green, G.S. Stein, and J.L. Stein. 1986. Human histone genes map to multiple chromosomes. Proc. Natl. Acad. Sci.

83: $3185-3188$.

Wang Z.-F., T. Krasikov, M.R. Frey, J. Wang, A.G. Matera, and W.F. Marzluff. 1996. Characterization of the mouse histone gene cluster on chromosome 13: 45 histone genes in three patches spread over $1 \mathrm{Mb}$. Genome Res. (this issue).

Wells, D. and L. Kedes. 1985. Structure of a human histone cDNA: Evidence that basally expressed histone genes have intervening sequences and encode polyadenylated mRNAs. Proc. Natl. Acad. Sci.

82: 2834-2838.

Wu, R.S. and W.M. Bonner. 1981. Separation of basal histone synthesis from $S$ phase histone synthesis in dividing cells. Cell 27: 321-330.

Zweidler, A., G. Stein, W. Stein, and W. Marzluff. 1984. Core histone variants of the mouse: Primary structure and expression. In Histone genes: Structure, organization, and regulation (ed. G. Stein, W. Stein, and W. Marzluff), pp. 373-395. John Wiley and Sons, New York, NY.

Received March 14, 1996; accepted in revised form June 14, 1996. 


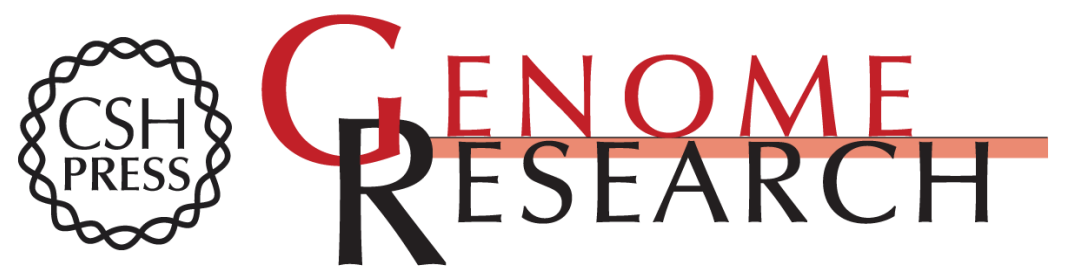

\section{Characterization of the 55-kb mouse histone gene cluster on chromosome 3.}

Z F Wang, R Tisovec, R W Debry, et al.

Genome Res. 1996 6: 702-714

Access the most recent version at doi:10.1101/gr.6.8.702

References This article cites 36 articles, 12 of which can be accessed free at:

http://genome.cshlp.org/content/6/8/702.full.html\#ref-list-1

\section{License}

Email Alerting Receive free email alerts when new articles cite this article - sign up in the box at the Service top right corner of the article or click here.

\section{Affordable, Accurate Sequencing.}

To subscribe to Genome Research go to: https://genome.cshlp.org/subscriptions 